\title{
San Mateo County Place-Naming ${ }^{1}$
}

\section{ALAN K. BROWN}

\section{Method and usage}

S

an Mateo County lies just south of San Francisco, and consists of 454 square miles of central California. The writer has collected approximately 1,100 names, now or once used for landmarks in the county. $^{2}$

It is hard to summarize such a study. On the one hand, any systematic findings, however limited, should be of interest. On the other, a discussion that limits itself to well-known names, or even to difficult or methodologically interesting ones, leaves too much untouched. A purely anecdotal presentation of raw material is sometimes felt to be as useful as any. The approach of the present article, however, is to apply a few general points of inquiry to the material, and to use some of its more interesting examples as illustration - all in an exploratory way.

A strong chronological emphasis in this study probably owes as much to the necessities of the investigation as to the compiler's tastes. ${ }^{3}$ San Mateo County has a short recorded history, less than

1 Professor Frederic G. Cassidy read this study in a somewhat different form. Its appearance as an article is due largely to his advice, which is warmly appreciated.

2 About 1,160 names, counting dubious cases; an even 1,100 by strict count. In the form of an alphabetical gazetteer with additional notes (mostly on street names) the study has been deposited with the San Mateo County Historical Association, at the College of San Mateo.

Names not collected include those of schools, hospitals and other institutions (on a priori grounds); small urban and large countryside parks (partly for practical reasons); most ranches and estates. Names for fields or fenced grazing grounds are so scarce or ephemeral as to defeat systematic collecting. In the Pescadero district "the Smith hills" usually means merely 'the hill land on Smith's ranch.' An attempt was made to collect all road names, but not those of suburban streets. For the latter, as for subdivisions, information is easily available in county records.

3 The material was collected between 1954 and 1956, and between 1958 and 1960. Courthouse records of San Mateo, San Francisco, Santa Clara and Santa Cruz counties (each of which has included some part of the area studied) were thoroughly searched and heavily used. Old newspaper files were almost as useful. Sixty-four 
two hundred years, but the changes have been many, sudden, and extreme. ${ }^{4}$ In 1900 there were twenty-seven persons per square mile, and there are now about a thousand. That nineteenth-century rural names, indeed most of the names still carried on the maps for natural features, are unknown to most of the population goes almost without saying; yet at the time this study was undertaken there were a few old people in the county who used Spanish place-names never adopted or even recorded by Anglo-Americans. Outside of the urban areas, minor names going back to the very first American settlement are carefully retained by the first families of Pescadero; at neighboring San Gregorio the present landowners' names are the only terms of reference used. Many older names were known to few but hunters; many newer ones in the mountains are due to lumber-company employees $;^{5}$ at the fringe of suburbia are found. small, simple nature-names (Frog Pond, Tick ridge, Rattlesnake rocks, Waterdog lake) bestowed by children on hikes.

For all this variety of usages, very few trustworthy accounts of the actual process of bestowing a name were found. More might have been known if a systematic study had been made of the naming

persons, of whom about forty are still living, contributed information that went beyond the recording of names now in use; but more informants might have been wished.

4 The only local place-name that can be proved to have existed before 1769 is New Year's or Año Nuevo point, named the punta de Año Nuevo by the navigator Vizcaino about New Year's day, 1603 (see Erwin G. Gudde, California Place Names, $2 \mathrm{~d}$ ed., Berkeley, 1960, s.v.). The translated form, which was used in a proclamation by the American military governor in 1849 , has been the regular local name since 1853 at the latest. It would have appeared on the Santa Cruz topographic sheet (1901; it is on the manuscript) but for the Geographic Board's review decision to use the half-Spanish form found on old nautical charts. The decision applied to an entire cluster of names, including New Year's creek, a post-1850 application. (From 1842 the Spanish name was arroyo de Lucia, after a runaway girl, Lucía Bolcoff; before that it had been arroyo de los Lobos, for sea-lions, not the seals memorialized in another early name, Lobitos varying with Lobos Pintos). New Year's creek is still on the County's maps and the local residents cling to New Year's point. Otherwise the official use is rapidly winning out; Año Nuevo island, where there was a government lighthouse, has been so called for some time.

5 "Hooker Creek" on the official county map is an error for Rooter gulch: a heavy piece of stump-clearing machinery was left there through the winter of 1936-7. A half dozen names were bestowed at once by a professional timber surveyor in 1947. 
of subdivisions and streets. Subdivision names are ephemeral, but a few survive as names of communities, preserving a suggestion of the advertising taste of their times like something in amber. Street names in a development, since they are more permanent, are often more systematic and soberer in expression; though even the best-known can of course now be effectively changed by local governments. The principal contractor is often given a small street to name, and normally names it after his wife, sister or daughter. In less organized areas the naming of small roadways is still sometimes in the public domain. Most new names for country roads are, in practice, thought up by the county planning commission; the older road names were gradually set by popular voice. ${ }^{6}$ The latter instance resembles the oftposited development from appellative phrase to proper name, except that the process in detail, so far as it can be investigated, seems always to consist of a selection from among competing tentative names. (Even in the case of such apparently natural developments as the La Honda road there is almost always a "Searsville and La Honda Turnpike" or "La Honda-San Gregorio county road" that went before.)

The naming of towns has at times been informal. ${ }^{7}$ Many city names have developed a colloquial short form (hypocoristic would be too strong a word). Redwood for Redwood City is attested from

6 A Woodside lady of my acquaintance was annoyed when her road or lane was named by the first group of residents to put up a sign. Near Redwood City a hill street was named Cervantes road by the developer, but was called Duggan's road for its first resident; the official county map, attempting to bow to local usage, labelled the wrong street Duggan Road and the name is disappearing. Before 1920 the initial official designations for county-built roads were rarely expected to survive. An exception is the Alameda (de las Pulgas), in 1886 laid out and named after the Pulgas land-grant by a number of landowners including Simón Monserrate Mezes, a former part-proprietor of the Spanish grant.

7 Redwood City - the county seat - was platted as Mezesville by S. M. Mezes in early 1854 amid "squatter troubles" - shootings, whippings and barnburnings. Mezes is said to have ridden his white horse down the street, alone, successfully challenging the whole settlement; but though the squatters later bought his lots, they refused his name. The place had been the Redwoods embarcadero, a landing and entrepôt for the Redwoods area in the mountains; Redwoods City appears in print in mid-1854, along with the present form. The loss of the $-s$ may have been grammatical or accidental; it led to the false legend that redwoods had once grown near the town. In 1858 a British traveler performed his countrymen's usual service of calling attention to the discrepancy between the word City and the reality. 
1857; Menlo and Half Moon for Menlo Park and Half Moon Bay are obviously similar. Since San Francisco is called the City, South San Francisco was shortened - presumably in fun - to South City as long ago as the 1890 's. On the other hand, when the village of Portola was swallowed up in the grander Portola Valley community about 1953, the newspapers began using the simple name as the short-form. Pesky, a former short-form for Pescadero, seems to have been too consciously funny to survive. The other Spanish names have all escaped shortening, as have the single-member Millbrae, Woodside, Belmont and Atherton (formerly Fair Oaks), and even North Fair Oaks. Burlingame can still be derisively called Blingum, a term invented in the 1890's (before the town itself appeared) to mock the supposedly anglophilic members of the Burlingame Country Club.

Fourteen of the United States Geological Survey's 71/2-minute topographic sheets, for which the basic field work was done between 1946 and 1957, cover the county. These maps originally showed about 330 of the names collected for this study; in 1962 the writer was privileged to have a number of his suggestions of additional names investigated and adopted by the Survey. If minor differences of form and spelling (some depending on very recondite historical information) are ignored, twenty-three names on the maps have forms inconsistent with present or past local usage, and seventeen are wrongly applied by the same standard. There are also eight examples of what may be called ghost-names, all originally names of triangulation stations now shown as place-names. All but eight or nine of the discrepancies, it should be noted, stem from earlier official maps. ${ }^{8}$

8 The community of Lobitos was wrongly called Tunitas on the 1940 Army Engineers' map, whose authority overrode the U.S.G.S. field engineer's report of 1952 until the new edition of the Half Moon Bay sheet, 1961. (Another common source of minor error on government maps is discussed on p. 168 below.)

A well-known range is Pedro mountain (sierra de San Pedro, $\sim$ de Santa Clara, $\sim$ de las Auras i.e. 'vultures,' in records of the 1830's and later). The map-name Montara mountain was a surveyor's mistake in 1854 and is not yet really popular, despite the existence of the village of Montara. Recent maps shift the popular name for the mountain to a lower ridge. 
To compare various types of naming - ultimately even to help distinguish them - one would like to use their relative numerical importance. For example, $17 \%$ of the names studied come from the period when the language of the country was Spanish. But information on the pre-1850 Spanish period is incomplete, ${ }^{9}$ to say nothing of other sources of error; and neither methods nor material are available yet for comparisons with other areas. To reach any safe conclusions, what is needed is a check for internal consistency.

By a consistent standard, though a much more liberal one than that properly used by the Geological Survey, about two thirds of the names collected were still in use in the county in the 1950 's. ${ }^{10}$ Only $8 \%$ of these surviving names come from the Spanish period. There is no such disparity between the percentages of names known and surviving from more recent periods, even though post-1850 sources are much more complete. That is, Spanish-period names have dropped out of use more than others, and the mechanism operating against their survival can be presumed to be the difference in population and language since 1850.

There are other instances in which a given type of name ranks much higher among surviving names than among the whole collection. It can then safely be assumed that either the records have slighted this type, or it has for some reason been retained oftener than other kinds. Obviously the consideration of names by period is a special case in which the changing nature of the records is likely to have peculiar importance.

For convenience, the two types of proportions $(17 \%$ und $8 \%$ respectively in the case of Spanish names) can be called the wholepercentage and the survival-percentage. If the whole and surviving totals on which they are based are sufficiently different, a comparison of the percentages should give significant results even for very small

${ }^{9}$ So in 1828 a missionary's report lists one otherwise unknown and all the known Spanish names between San Bruno and San Mateo, with a passing reference to "otros nombres, que dan alos Aguajitos, Zanjas o Piedras" (Chancery Office of the Archdiocese of San Francisco, Taylor Collection, no. 2048).

10 If road-names are included in the counts, $66.6 \%$; if not, $65.3 \%$. It is assumed that all surviving names are known, and that all names are known to be pre- or post-1850. (Some English names may in fact be from unknown Spanish models; but all cases of "total translation" have been counted as new namings, and the effect on the assumption can only be slight.) 
categories. Close agreement between the percentages, or a constant relation in most instances when many cases are considered, must indicate that the sources used are at least representative. ${ }^{11}$ Further uses depend on the material being compared; for areas with longer histories of place-naming, the method might be easier to apply and might show, for instance, whether there are fixed rates at which names disappear from use. In the present study original counts and tabulations cannot be given, only a few selected results, all of which, however, seem reasonable and consistent; and it is necessary to state that without this method most of the classifications and conclusions of this study would not have been attempted. ${ }^{12}$

11 In the case of Spanish-period names, the excess of survival-percentage necessarily balancing the excess whole-percentage for the period was distributed in due proportion over four later periods of approximately equal length considered. A crude check for this sort of consistency is easily made (as, e.g., by looking down the columns in the table given below) and apparently could be handled mathematically so as to give much more interesting results. Even as it is, ambiguous results can usually be resolved by further experimental analysis and reclassification of the material.

12 Since the above was written I have read Gerhard Bauer's Die Flurnamen der Stadt Saarbrücken (Bonn, 1957), which claims (p. 12, in introduction) to have an approach "corresponding throughout to the statistical method" developed by Adolf Bach and his followers - evidently the method based on very close logical and grammatical classifying of place-names (Bach, Deutsche Namenkunde II, die deutschen Ortsnamen 2, Heidelberg, 1954, §551, pp. 266-267). In addition, however, in Bauer's graphs on pp. 283, 292, 299, and 308 separate totals of known and surviving names are entered to suggest, roughly, the contributions of six centuries. Corresponding percentages are given in accompanying tables ( 3 , Gesamtnamenschatz, $\S 4$, heutiger Namenbestand for each parish studied), but are not systematically compared. When compared, they seem to show the expected survival-percentage excess for the latest periods that suggests a constant of temporal attrition on the name-vocabulary. The figures in the second table on p. 312, though fewer, give a much clearer result, apparently because the dubious "appellative [prepositional] constructions" have been removed. Converted to percentages (the totals differ slightly from those given in the text), the material seems to show highly consistent relationships.

The comparison of whole and surviving percentages is, I think, like the approach of "glottochronology" insofar as both compare the compositions of two sets with some common elements, but unlike in not requiring one of the sets to be homogeneous. If, on the other hand, surviving elements are to be compared with elements found only in other sources (as by Bauer, pp. 309-311), there is much less certainty of what the relationships signify. Bauer's book is obviously a model of its kind, especially in the presentation of material at length. 


\section{Types of naming and types of names}

Despite a number of boundary changes San Mateo County has never been either a naturally well-defined or a demographically logical unit; ${ }^{13}$ but the discussion of regional variations can be postponed. In order to discuss the names as a whole, it will first be useful to divide local history into somewhat arbitrary periods.

From the year 1769 the area was repeatedly penetrated by Spanish exploring parties, who bestowed some permanent names and some ephemeral ones, the latter not included in this study. After 1777 there were settlements nearby; the first within the present county occurred in 1786. In the 1830's a few dozen English and American sawyers settled in what they called the Pulgas redwoods, and left two or three recoverable place-names, none, however, permanent. As mentioned above, $17 \%$ of the names studied were given in the Spanish period, 1769 to 1849 , but only $8 \%$ of the surviving names.

13 In fact there are two non-coordinate region names which are much oftener used, if not better known, than the name of the county. Perhaps because of a fine map published by the Coast Survey in 1869, it became common in San Francisco about 1870 to speak of "the (San Francisco) peninsula," including therein the city. Inland was "down the peninsula," a phrase still used in this sense. After 1890 and even more after the 1906 fire, the new suburbs from five to fifteen miles down the railroad appropriated the term to themselves as the Peninsula. As the urban belt grew further to the southeast, the new name followed with some delay; after 1945 it included towns beyond San Mateo County, and by 1960 extended to (and could sometimes include) the city of San Jose, fifty miles from San Francisco; but also by then was less often used for the suburbs to which it had first been applied. Though the preposition used is still on, not in, the name is coordinate with the City, the East Bay, and Marin.

A stretch of ocean shore south of San Francisco was referred to as la Costa (par excellence) in Spanish times. Americans adopted this in the 1850's and translated it to the Coast in the '60's. Later the county-seat newspaper used the phrase "the Coast side" (of the county), which in connection with real-estate booming around 1900 became reinterpreted as a name, the Coastside. The shore north of Pedro mountain had been nameless; from the 1920's it was sometimes called the North Coast; but in 1958 it incorporated as the city of Pacifica. The most commonly expressed reason for the incorporation was that the settlements belonged to neither the City, the Peninsula nor the Coastside, and needed an identity.

It seems necessary to assume a development from appellative phrase to name for the Peninsula and the Coastside - but for these two alone, out of all the names studied. 
The English language came to dominate between 1850 and 1865, when about five thousand Americans (native or soon-assimilated) arrived on the heels of the Gold Rush and established small ranches and shingle- or rail-splitting partnerships. There were a few crossroads villages. Nearly $30 \%$ of the names collected come from this fifteen-year period.

Another $30 \%$ of the names originated in the twenty-five years, 1866 to 1890 . Most of the county then consisted of established rural districts. A railroad had been completed in 1864, and by 1890 nearly half the population was living in four towns, the largest of which had 1,572 persons.

In the next thirty-five years, from 1891 to 1925 , only about $15 \%$ of the names systematically studied were given. This figure ignores street names: after 1900 the towns became suburban to San Francisco, and the population increased fivefold by the end of the period. The rural population began a rapid turnover in the 1890's and has not stopped changing since.

Between 1926 and 1959 (the terminal date for this study) the old suburban towns had coalesced and spread far into the hills. Only about $13 \%$ of the surviving names studied, and $9 \%$ of all the names, came out of these last thirty-five years. Some of the decline must be due to the new patterns of settlement and society (apparently the advent of the automobile has caused most names for short steep grades to be forgotten; arable valleys and flats are much less often named). ${ }^{14}$ But also the time of first settlement and namegiving is past, and perhaps the opportunities are fewer.

Most serious studies of naming seem to produce their own schemes of what things can be named for; in other terms, of what the names can express. The classification used here has been at least partly suggested by the material in hand - but has been adopted with some misgivings, since there is no lack of general schemes that have been proposed as frameworks for comparative studies. ${ }^{15}$

${ }^{14}$ See under hill in the register of generic terms at the end of this article; also, the table below, "Valleys."

15 Bach (loc. cit., note 12 above) warns against departing from his own classification and thereby destroying the basis for comparison. But obviously work done on a different language and culture and continent must be more inductive, at least at first. The theoretical explanation ("closeness of description") and the order of the classes used below are an afterthought. The scheme resembles very closely 
Among the names studied, those which express a very close, literal or nearly literal description, can be set off: Green valley, Bridge street seem to form a recognizable type. In the two earliest periods (from 1770 to 1865 ) this type made up nearly half of the names given $(47 \%, 45 \%)$. Its later decline is noteworthy: $19 \%, 11 \%$, $12 \%$ for the last three periods; among street names, to nearly nil.

Some of the decline can be attributed to the popularity of making place-names from personal names of inhabitants (Smith gulch). In the initial American settlement only about a quarter of the names given were of this type; in 1866-1890, over a half. (There was an identical change in Spanish names between the pre-1850 period, when literally descriptive names dominated, and the period 1850 to 1865, when over half of the new names were for residents around the old settlements: e.g., cañada de Apolonio - still on the maps as Apanolia (sic) creek - for Apolonio Rodríguez). Such naming for local residents has also declined (38\% in 1891-1925), but remains somewhat productive $(14 \%$ in the latest period, street names not counted).

The transfer of an existing place-name to another local feature, or better the naming of one landmark after a previously named one, is common ( $23 \%$ in the earliest period, $43 \%$ in the latest). If a distinction is made between names drawn from such artificial features as roads and towns (Grabtown gulch, San Mateo avenue) and naming after natural landmarks (Bear Gulch creek), it is seen that the latter type has declined very steadily, from the earliest period $(19 \%)$ down to the latest $(8 \%)$. Conversely, names derived from those of man-made features have now become the most common onomastic type of all (except in street names), having increased from $8 \%$ to $17 \%$ to $35 \%$ in the last three periods. Yet in 1866-1890 this percentage was slightly lower than in 1850-1865: perhaps the general decline in the more closely descriptive types of naming started to affect this type, but was checked by the proliferation of available town and road names. The proportion of names containing an institution or company name (the Macco Pit), though always smaller,

that of George R. Stewart (Names, 2 [1954], 1-13; 4 [1956], 119-21), which is based on "mechanisms rather than motives" for naming. If the need for comparisons is to prevail over the natural tendency of trial-and-error development, Professor Stewart's classification, being based on the widest experience, should be generally adopted. 
shows the same progression with the same slight early decline ( $1 \%$ to $4 \%$ to $3 \%$ to $7 \%$ to $8 \%$ ).

A sort of portmanteau classification can be set up for names that express matters still more extrinsic to the thing named, but connected with it at least by locale: for example, names given for incidents (the Battleground, for a dawn-to-dusk fistfight over land claims) or for the nationality of the first settlers (Irish ridge). This kind of naming was most popular with early explorers $(10 \%$ of pre-1850 names) and again, for some reason, in 1890-1925.

Conventional or honorific names - that is, those most irrelevant to the feature named (San Pedro y San Pablo, Lincoln hill) - were also common in the earliest period (12\%; and many found only once in explorers' journals have not been counted). They were very rarely given between 1850 and 1890 (3\% of the period), but probably include two thirds or more of all names ever used in the county, if modern street names are added to the total. With street names excluded, the conventional type accounts for $15 \%$ of the names of the latest period. ${ }^{16}$

Geographical terms that can be used as the generic element in place-names have been subjected to a number of recent studies, mostly from the point of view of regional distributions and vari-

16 Such changes in fashion can be very deliberate. During the nineteenth century the present principal business street of Redwood City was variously called $A$ street, Court street (for the courthouse), and Bridge street. In 1904, among many similar changes, the name Broadway was officially extended to the whole street from a roadway in a new subdivision. The city council justified its action by stating that the old-fashioned-sounding (sc., descriptive) names were inimical to the boom spirit. (For a similar occurrence in Denver at the same time, cf. Gene Fowler, $A$ Solo in Tom-Toms, N.Y., 1946, pp. 173-4.) Nowadays, of course, developers are more likely to invent descriptive-sounding names: Farm Hill road (but here road always has the more prominent stress and pitch commonly given to the more exotic avenue and boulevard).

It is not being claimed that the above classification of onomastic expression is perfectly satisfactory for material other than that used in the present study. For example, if $A$ street had been deliberately applied to the main street, or San Pedro $y$ San Pablo had been used (as it often is) for a double tree or other two-part feature, these names of conventional appearance would have been in some sense literally descriptive. Their assignment to the final class would then be (as in Stewart's scheme) solely due to their derivation from proper names. 
ations. ${ }^{17}$ It not uncommonly happens that a widely-known generic is substituted for a more regional or dialectal one. ${ }^{18}$ Even more common, apparently, is the tendency to dismiss as "informal" or "local" all place-names that contain no recognized generic term, or to give them an approved generic when they are written down (thus such well-known names of areas in San Francisco as the Potrero, the Mission, or the Excelsior become the Potrero district or hill, the Mission district, and so forth). From the most general point of view, then, there are certain generic terms used to make names of a standard type or types, and there are names that do not conform to such a type. The situation may reflect the fact that the meaning of a geographical term is determined by or resides in its applications; that the most stable and therefore determining application (more perhaps for geographical than for most other types of terms) is the use of a name; and that therefore a so-called metaphorical extension of a term used in names is the language's normal resort for recognizing otherwise unspecifiable entities, that is, for naming a landmark that is not one of the usually-named types, or in the longer run for creating a new appellative geographical term. ${ }^{19}$

On a local or regional level the situation seems to be clear. There is a limited vocabulary of standard generic terms, defined by its members' plural occurrence in place-names, and at least potentially limited with respect to the local appellative geographical vocabu-

17 Robert C. West, "The Term 'Bayou' in the United States: A Study in the Geography of Place Names," Annals of the Association of American Geographers 44 (1954), 63-74; Wilbur Zelinsky, "Some Problems in the Distribution of Generic Terms in the Place-Names of the Northeastern United States," $i d .45$ (1955), 319 349; Meredith F. Burrill, "Toponymic Generics," Names 4 (1956), 129-37 and 226-40; H. F. Raup, "Names of Ohio's Streams," id. 5 (1957), 162-8; Donald B. Sands, "The Nature of the Generics in Island, Ledge, and Rock Names of the Maine Coast," $i d .7$ (1959), 193-202; E. Wallace McMullen, "The Term Prairie in the United States," id. (1957), 27-46.

18 The articles just cited draw their materials from printed maps (or, occasionally, gazetteers). West (pp. 65-6), Zelinsky (pp. 321-2) and Sands (pp. 193-4) briefly mention the possible inaccuracy of such sources because of such substitutions. For one example, see the register of generics below, under field.

19 See the remarks by Burrill (p. 129); further now Burrill and Edwin Bonsack, Jr., in Problems in Lexicography, ed. F. W. Householder and S. Saporta, Bloomington or The Hague, 1962, pp. 183-199. For the creation of a new generic, see chalks below. 
lary. ${ }^{20}$ Further, there are or can be differences between the appellative and the generic use of the same term - as will be shown below in the register of generics. Finally, if not necessarily, in San Mateo County in American times names without standard generic terms have been only about one in ten, and have gradually become less popular. ${ }^{21}$ The type is commonest among literally-descriptive names, of which nearly a quarter have lacked, and lack, such generics. It is least important among naming after personal names and place-names, obviously because of grammatical awkwardness. (However, there was once a road-grade called the Macy that went by Macy's house over Dave Macy hill.) A careful investigation shows no further statistical differences between this type of naming and others in terms of the categories already used.

When a geographical term not in the local lexicon of standard generics is used in generic position, the metaphorical effect is very striking: "pseudogeneric" is a useful term for names of this sort..22 In a quarter of the present cases, the metaphor has been applied to what could clearly have been named with a standard generic (e.g., Rocky Point for a hill). The other three fourths of such names are about evenly divided between clearings (for which the standard generic, such as it is, is a localism - see field below), various kinds

20 The word 'hogback' has been fairly commonly used of ridges, but never appears in a name. The studies cited seem to use frequency of occurrence as the criterion for separating their "true" generics from those used in "metaphorical names." Zelinsky (p. 320, note 6) has noticed the possibility of differences between the appellative and generic vocabularies.

21 Among all Spanish-period names, $20 \%$, but only $6 \%$ of those surviving; $1850-1890,11 \%$ (survival-percentage $2 \%$ less); 1891-1925, 9\%; 1926-1959, $6 \%$; and of all names, $11 \%$ (9\% of survivals).

${ }^{22}$ George R. Stewart, American Speech 25 (1950), 198: "Pseudogenerics, or what might be called the nonce generics." A different construction has since been called "false generic," e.g., prairie in a town-name like *Jones Prairie. For the purposes of this study, however, terms so used are considered merely part of a simplex (the result of naming after a name), like Gulch in the specific part of Bear Gulch creek. Stewart's "absolute generic," for which his example is The Washboard, is here considered a specific simplex, without a generic. Instances like the Mountain, where the word is elsewhere a standard generic, are no immediate difficulty, for they can if necessary be called half-appellative rather than generic. Note that *the Hogback is a plausible form (in fact, dubiously attested), whereas *Jones Hogback is not. The Mesa is a direct descendant of a Spanish usage; the word is understood but not otherwise used locally. 
of elevations, and miscellaneous features difficult to describe (vegetation, small bodies of water, a salt-marsh hotpond and, if a pun counts here, a steep sharp road-turn: Grecian Bend). ${ }^{23}$

Names with no grammatical generic term are a little commoner than the last-mentioned type, and are also used in interesting ways. When the word the is prefixed, it seems to be felt to refer over to an unexpressed generic idea, perhaps the class or notion 'landmarkobject.' ${ }^{24}$ At least, such names seem to be given or become appropriated to recognizable objects: the Skyline, a mountain ridge; the Elbow, a slough; [ðə mo're] - not written; from French marais a marshy flat; the Butano, a creek, a small flat once used for picnics, and a forest. ${ }^{25}$ On the other hand, simple names without the definite article, when not applied to towns, apparently refer to simple locations rather than to specific types of landmarks: Pine Stump,

${ }^{23}$ An area of steep canyons is the Virginia Timbers. Here "timbers" has expressive, not denotative value - it is not otherwise used locally, though the Cross Timbers of the Plains may have supplied a model. In fact the name is a backformation from "Virginia Timber and Lumber Company," with an apparent analogical restoration of the plural form for grammatical reasons (see below).

${ }^{24}$ In water-names such forms are traditionally explained as simple ellipsis of, e.g., "stream" or "river." Alexander Gill, Logonomia anglica, 1621, ed. Jiriczek, Strassburg, 1903, p. 82: [Nomina] Propria etiam propter eclipsin assumunt ðe: vt, Hj waz droun'd in ðе Temz, subintellecto flumine aut aquâ; in fluuio Tamisi, aut in aquâ Tamisis submersus est. The explanation is seriously weakened by the vacillation between the "understood" river Thames and Thames(') water (Gill's translations from English are very close). In the United States one sometimes doubts whether to supply creek or river to a name, and the type "the Yukon (river, country)" has been well known. In the Pescadero district of San Mateo County, as elsewhere, forms like the Waterman can apply to a watercourse and a place simultaneously or separately, or can have almost any quasi-generic term (pines, area) suffixed as needed. The maps, however, always supply creek or canyon.

${ }_{25}$ The Skyline, the county's principal natural landmark, was named shortly after the State Highway Act of 1919 from the new Skyline boulevard (itself always abbreviated as Skyline, with no article; it extends far north of the mountain). The name replaced the antiquated Sierra Morena and the half-appellative the Mountain (still preferred on the coast side of the range; the settlers were sometimes called Mountaineers).

The applications of the Butano are distinct but complicated; those given above are the clearest. The Spanish usage was arroyo del Bútano for the creek, bolsa del Buitano for a now nameless peninsula (though part of the name is preserved in the Pocket ranch), and el Bútano for something unspecifiable (1816 "unas cañadas mui ocultas que hay por el Bútano"). Which if any of the modern applications descends from this original Spanish one it is impossible to say. (The interpretation of the 
Watertrough, and Dry Lake are no longer marked even by the objects they were named for. ${ }^{26}$ There are twice as many such names as there are genericless names with the article.

Official generics for the great new highways ("freeway" and so forth) vary from state to state, and this uncertainty may be the reason for an incipient use, for major roads, of uncompounded names prefixed by the article: what used to be called Bayshore when it was, in full, the Bayshore highway is now more commonly the Bayshore (freeway); the $\mathrm{El} \mathrm{Camino} \mathrm{is} \mathrm{now} \mathrm{heard} \mathrm{in} \mathrm{place} \mathrm{of} \mathrm{El} \mathrm{Camino.}{ }^{27}$ At any rate, the figures collected show that such names are now used as freely for man-made landmarks as for natural ones.

Other grammatical constructions are rare in the names collected. Except of course before a noun in the possessive case, the use of the with normal compound names is usual with highway, more or less optional with road, old-fashioned but still possible with creek (in the sense of 'stream,' not 'slough') and beach, and rare with gulch; also in the San Bruno mountain, and with lagoon. For the grammatical omission of the plural before a generic, ef. Redwood(s) City and, inversely, the Virginia Timbers above; also Green Oaks, a ranchstead, vs. Green Oak creek (both said to be from arroyo de los Encinos Verdes). The exception is Three Bridges gulch, a name apparently in use for only a short time. (There is a problematical recording of a

word as 'a cow-horn drinking cup' in California Spanish is due to Pablo Vasquez of Half Moon Bay - La Peninsula, San Mateo County Historical Association, Feb. 1960. Cf. Gudde, op. cit., s.v.)

Through the early 1860's, the village of Pescadero was frequently called the Pescadero, under direct influence of Spanish usage.

${ }^{26}$ The possible exceptions are possibly not simplices: Stone Dam, a lake; Stone Circle, a road intersection; Stone Fence, the area of a mile-long rock wall, built 1858, destroyed 1958 - "stone fence" is not in regional use. Five Points (a fixed name copied from the notorious New York place) is best described as a place at an intersection (of six streets since 1920). Intersections normally take the: e.g., the Circle, the Wagon Wheel, two names given by local conservation agencies to another sixway junction. Pine Stump was once a "shingle landing" where lumber was "gulched out"; at Watertrough teams were rested; Dry Lake had pond-beds; of Five Points and Four Points, the less said the better.

${ }_{27}$ There seems to be no connection with a puristic form the Camino long used by some of the local academic community. The full name $E l$ Camino Real was a Spanish appellative, resurrected as a name about 1900 and soon shortened. It need hardly be pointed out that the Spanish definite article is not present in the name in any real or useful sense. 
similar name in another place, at the time an Irish settlement: "the stream ... known as the Three Bridges"). Despite the close historical investigation, all that can be said of the possessive ending of personal-name specifics is that it tends to drop, where it existed; there is no indication that it was always present in such names. In Smith's creek it is probably preserved by the alternation with Smith('s) slough. King's mountain is another back-formation, which arose in the 1890's when Stanford students began asking the way to King's Mountain House, originally Frank King's Mountain Brow saloon. Map makers, by suppressing anything that sounds like a possessive ending, have fallen into a number of traps: e.g., "Haskin hill" for Haskins(') hill.

The pre-specific occurrences of camp, lake, mount, and point are dealt with in the register at the end of the article. The type North fork of the Waddell (creek) tends in several instances to be simplified to North Waddell creek. Local newspapers in the course of a campaign for safer driving conditions applied an epithet to a name: Bloody Bayshore. Upper and Lower and Little are stable parts of distinct names; Big is not, but is occasionally added for increased distinctiveness. A Frenchman's Au Bel Air ('Fresh Air') House gave rise to Belair creek, $\sim$ island, $\sim$ channel, and Belle Aire (sic) school and subdivision by dropping of the relic locative of European tavernnames. Spanish names before 1850 have the full form, e.g., arroyo (nombrado) de los Pilarcitos; arroyo Pilarcitos is recorded only later.

The writer has the impression that final words most often bear the full accent, but that specifics can be accented when they are personal names (Green slough) or when a number of other names with the same generic term occur in the same vicinity or in the same frame of discourse (the commonest names with shifted accent seem to be those containing street, road, creek; also, Upper, Lower). At least in citation-forms, the writer tends to avoid such shifting pronunciations by making a split between pitch and stress: \# ${ }^{3}$ Sàn Francisco + báy ${ }^{1} \#$ \# ${ }^{2}$ San Fran ${ }^{3}$ cìsco + báy ${ }^{1} \# .^{28}$

28 On these matters cf. James B. McMillan, American Speech 24 (1949), 247-8; Dwight L. Bolinger, id. 33 (1958), 8-20; Francis Lee Utley, Names 11 (1963), 164-5; Georg Hempl, Modern Language Notes 11 (1896), 238 (cited by McMillan; Hempl's most interesting remarks are on the varying stress of Ober- and Unter-). 
The names studied have been arbitrarily classified by the general types of landmark named. The most striking result is that waterfeatures (mostly streams; also lakes, sloughs and the like) have been named from three to six times as often as have valleys, hills, shoreline features, simple locations, or unclassified features. ${ }^{29}$ Other conclusions can be drawn from the table.

\begin{tabular}{l|c|c|c|c}
\hline & $1770-1850$ & $1851-1890$ & $1891-1925$ & $1926-1959$ \\
\hline 1. Water & 15 & 61 & 13 & 12 \\
& -7 & +1 & +4 & +3 \\
\hline 2. Valleys & $\begin{array}{c}17) \\
-8\end{array}$ & $\begin{array}{c}(69) \\
-1\end{array}$ & $\begin{array}{c}(14) \\
+4\end{array}$ & $\begin{array}{c}(3) \\
+2\end{array}$ \\
\hline 3. Hills & 7 & 68 & 15 & 11 \\
& -2 & -1 & +1 & +3 \\
\hline 4. Shore & 10 & 56 & 19 & 16 \\
& -3 & +1 & 0 & +3 \\
\hline 5. Towns & 3 & 51 & 26 & 23 \\
& +1 & -7 & -3 & +7 \\
\hline 6. Simple locations & $(35)$ & $(52)$ & $(9)$ & $(4)$ \\
& -24 & +15 & +6 & +5 \\
\hline 7. Other & $(13)$ & 61 & $(14)$ & 12 \\
& -13 & 0 & +4 & +8
\end{tabular}

TABLE

Kinds of landmark named in each period, per cent of kind.

The upper line after each type of feature gives the mean of whole-percentage and survival-percentage for each period, except that figures in parentheses are wholepercentage only. The lower lines give the excess of the survival-percentage $(+)$ or of the whole-percentage (-), whichever is larger. Italicized figures are apparently heavily affected by compensation for other periods.

${ }^{29}$ Here, at last, some comparative material is readily available. The following percentages for Dane County, Wisc., are drawn on my own principle of selection from the material in Charts I and II, pp. 39-40, of F. G. Cassidy, The Place-Names of Dane County, Wisconsin (Publications of the American Dialect Society no. 7, 1947). The San Mateo County figures are the average of whole- and survivalpercentages.

Names for water-features, Dane $35 \%$, San Mateo $38 \%$; valleys, Dane only $5 \%$, San Mateo 13\%; hills, Dane 16\%, San Mateo 13\%; shoreline, Dane 7\%, San 
It is a common observation that European river names are often very ancient. Though local creek names (there are no rivers) taken as a whole show no special potential for survival, there is no stream in the county over four miles long that does not have a Spanish name. ${ }^{30}$ Otherwise, as the table demonstrates, the naming of different types of features has had a uniform trend, at least since 1850. The town names are peculiar only in their low survivalpercentages: that is, in the periodic changes of population they are lost no more often than other names, but when they are lost they are always replaced, as other names are not. ${ }^{31}$

A crude separation of landmarks into natural and man-made kinds (including roads) shows that the natural ones have been named about equally for their own qualities (Green valley), for persons, and for everything else. Towns and roads, on the other hand, have always been most commonly named after local places, but recently have more and more often been given conventional and irrelevant titles.

\section{Languages}

Local place-names have been bestowed in the English, Spanish, local Indian, French, Italian, Chinese and Russian ${ }^{32}$ languages. Only the first three of these have been important enough to leave more than one or two readily recoverable names. The writer regrets

Mateo 10\% (Dane has about 35 miles of lake- and river-front; San Mateo has 80 miles of bay and ocean shore). The results are strikingly alike.

${ }^{30}$ And none under three miles that does. I reached this unremarkable observation via a remarkable 35/54 ratio of whole- to survival-percentage for Spanishperiod water names by per cent of period (not kind, as in the table).

31 The result of a conflict between usages is almost always the disappearance of both, with or without the appearance of a third. From the middle 1850's a village was called the pueblo de San Benito in Spanish, and Spanish Town by the Americans (and present Main street was at first the calle Real and Greaser street). In 1870 the town fathers adopted the present name, Half Moon Bay, which had belonged to an adjacent district and was a common postal address. The older American name, now written Spanishtown, was, however, in common use up to the 1920's and is retained in legend and the name of the town's well-known exhibition drill team.

${ }_{32}$ М. Д. Тебенков, Атлась сбверозападиыхъ береговъ Америки, St. Petersburg, 1852 (first ed. Sitka, 1848) has what seems to be present Pigeon Point labeled M[ыс] тонкои, 'Thin point,' a designation which is common but not very applicable; Pescadero point is still in the immediate vicinity, and it is conceivable that тонька 'fishery' was used, as a translation. 
having been unable to investigate Chinese usage. Portuguese in its local manifestation has been a numerically important tongue, but (like Italian) it apparently merely adopts Spanish and English names by translating the generic portions at most. The figure illustrates the critical period of changes in the dominant languages, ending just before living memory. ${ }^{33}$

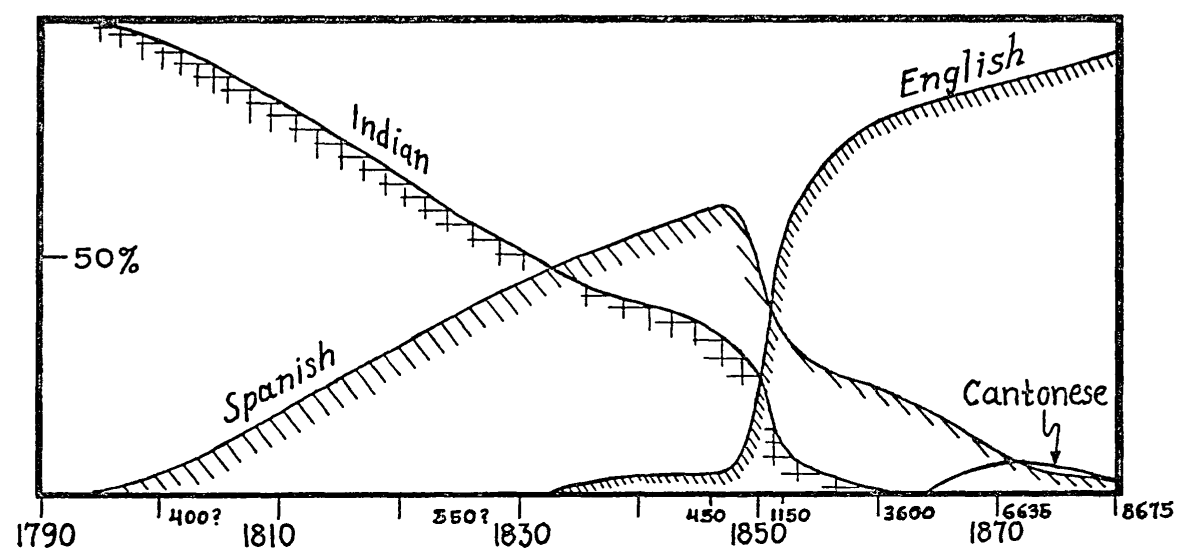

Per cent of the population speaking various languages, 1790 to 1880 . The small figures are the approximate total population.

About thirty names of Indian villages, or of sites often inhabited, can be culled from Spanish mission records. Some other Indian place-names must have been used as long as there was an Indian community; but most of the present names popularly said to be Indian are not, ${ }^{34}$ and most of the recorded village names cannot be translated on the basis of the few short word-lists that exist for the language.

${ }^{33}$ Mission records suggest an aboriginal population of about a thousand, who had been settled on mission ranches or removed from the county by 1800 . A census of the settlements made in 1828 is imperfect. For the year 1846, when California came under American control, a population of 450 is deduced from backward extrapolation and one or two direct statements. The manuscript schedules for the state census of 1852 and the federal census of 1860 and 1870 were used in order to estimate the number of speakers of various languages.

34 Butano is locally supposed to mean 'friendly meeting place' - obviously because it has been a picnic spot. See note 25. Tahana gulch ([tə'hænə]; spelling from recent U.S.G.S. map) is indeed not yet explained, but probably non-Indian. 
Buri Buri $[$ 'bjər + 'bjør $\mathrm{I}$ is now the popular name of a community or district in South San Francisco. Some sort of place or landmark here (the form of the name is most unusual) was recorded as "Guriguri" in Spanish orthography in 1782; the Spaniards soon (as is normal before a back vowel) substituted their voiced bilabial for the [w] glide and spelled the name "Buriburi, Vurivuri." It came to be applied to a great land grant and after 1850 appears only in connection with property titles, with the English pronunciation shown by the occasional spelling "Burri Burri." From about 1900 to 1926 (when the name was changed to Broadway) there was a Buri Buri avenue at the south end of the old rancho, eight miles from the original site. However, the aboriginal application and pronunciation are found strangely surviving in a record of 1864 that refers to a small tract as the Wory Wory ranch. It is a coincidence that the "Rancho Buri-Buri" subdivision was laid out on the same spot in 1946, and that the name has since been simplified..$^{35}$

Pulgas creek and the Alameda de las Pulgas may hide an Indian name under a translation. The village (present San Carlos) was named Cachanigtac (Spanish spelling; the $g$ must have the value [\%], and the last syllable is a locative suffix usual in place-names). In the Monterey dialect, "rach-kachu, rashkachsu" meant 'bedbug' or something like it, and "kashup" is given as the word for "mosquito' at Santa Cruz;36 by 1779 the Spaniards were calling the village las Pulgas, 'the Fleas.'

The Spanish names, except for those given by early explorers and missionaries and some given after 1850 , reflect a dialect and usage brought from Sonora and Sinaloa. By comparison with Englishlanguage place-naming, the salient feature of local Spanish is

${ }^{35}$ It is also a coincidence that Madison S. Beeler has proposed a somewhat similar history for Colma, a nearby name for which popular explanations are many but unconvincing (Western Folklore 13 [1954], 276-7). The resemblance of the name to a reported local Indian word for 'moon' (one apparently without cognates) must however be accidental, since Colma station was named by the railroad in January, 1872, at the same time that the next station was named Baden ['bedn] ; and Baden and Colma are a city and a village in the Swiss and Italian Alps, respectively. For the peculiar later history of the name, see Frank M. Stanger, South from San Francisco (San Mateo, 1963), pp. 157-9.

${ }^{36}$ California Indian Linguistic Records, Univ. of Calif. Pubs. in Anthropological Records 15, nos. 1-2, pp. 22, 167; California Farmer, April 5, 1860, p. 59. 
the great number of simple names for locations considered simply as such (see note 21, and the table above). There are very few examples of the "pseudogeneric" type so notable among English names, and even these few can be otherwise interpreted. The more commonly used generic terms have exact equivalents in English, and those that do not, have sometimes influenced the use of English terms in names (see the register below). Yet there has been a detectable difference between the two languages in the treatment of the less commonly named kinds of landmarks (see the table, line 7).

Between 1850 and 1860 the number of Spanish speakers in the county doubled. The immigration, largely from Mexico and Chile, produced a few changes in place-naming, most notably the use of cañon, and of cañada to mean 'creek'. Later the language was spoken in scattered neighborhoods, until around 1900 at Half Moon Bay and Portola Valley.

Spanish usage directly influenced American place-naming during the period of the first American settlement, until the middle or late 1860's. Only one or two Spanish names were taken over after that time, and many that had been in general use were forgotten. ${ }^{37}$

The pronunciation of Spanish names adopted into the English of California has been treated before, ${ }^{38}$ and most of the rules of the process are the ones that have governed loan words for centuries. Locally the rule that seems to take priority is the one by which Spanish /a/ becomes [æ]: arroyo de las Garzas, for example, became Gazos ['gæzəs] creek, apparently because the original consonantgroup could not follow [æ] in English. ${ }^{39}$ The stressed vowel of San Mateo was adopted with little change as [sæ̃mə'teo] toward 1850 ("samateo, San Matao" are occasional spellings found early and

37 Occasional spellings in the town records indicate that Argüello street in Redwood City, named for the land-grant proprietors, was still pronounced [ar'wejo] about 1870. By 1880, however, the present spelling pronunciation [ar'gwelo] was used.

38 J. B. Vasché, American Speech 6 (1930-1), 462; R. Shafer, id. 17 (1942), 239.

39 A record of 1860 suggests another solution by the spelling "Gratios" (['græJəs] ?). The old local pronunciation of the Canyada and Cañada road was [1 kænI'ædə]; apparently both a [i] and an open juncture preceding the stress were impossible in the word. The pronunciation now is [kə'nadə] or ['kænədə], from the spelling - only the state highway division writes the tilde. 
late), but San Pedro was altered to Pedro ['pidro] by Irish settlers thirty or forty years later. Spanish / $\mathrm{i} /$, when stressed, is usually tense [i] now, though occasional spellings suggest it could also become [I] ("Pillersittos" for Pilarcitos creek [prlər'sitəs]); Purissima creek has [I, i]..$^{40}$ Some pronounce Butano $\sim$ with [u], but "Beutno Creek" in 1854 already shows the commoner ['bjutno, 'birtno, -ə].

In the Pescadero district unaccented vowels (especially final) in Spanish names are reduced to [ə]: Lobitos (usually "Lobetus" between 1860 and 1890) rhymes with Tunitas, ${ }^{41}$ and Pomponio $\sim$ was formerly written "Pomponia" or even "Pompony." The old spelling "San Gregoria" is prominently displayed on a roadhouse at the village, next to highway signs with "-o." Apparently this is the phenomenon that once led to spellings like "Calaforna, Calaforny": a reinterpretation of unstressed [i] as [ə], or vice versa. ${ }^{42}$ Speakers from the rest of the county (i.e., the area influenced by San Francisco) seem to distinguish final [o] in these names.

Wider investigations may conceivably show that the soundsystem of Spanish, rather than that of English, lies behind the translation of Spanish /a/ with the single value [æ] and of Spanish $\mid \check{c} /$ as $\left[\int\right] .^{43}$

About half of the known local Spanish names (nearly a hundred) have been taken over into English-language use through several processes. The commonest $(70 \%)$ has been to replace the generic

40 "Paresimo" in the 1850 's-60's rather suggests [i]. The double $s$, established in local spelling, may be an original Latinism (attested 1787) but is more likely American: the map spelling with a single $s$ sometimes is read as [z].

41 "So called from a small bush that grows superabundant at and about [the creek's] mouth, and its fruit is known to the present generation as sea apples" (Pablo Vasquez, 1892).

${ }^{42} \mathrm{Cf}$., for some of the discussion and an extraordinarily suggestive map, G. B. Pace, "Linguistic Geography and Names Ending in 〈i〉," American Speech 35 (1960), 175-87. Examples from elsewhere in the county may include saca (see below), since it is apparently ['seki] elsewhere, and the numerous names with adjectival China $\sim$ as the specific, now sometimes altered to Chinese $\sim$. Another reinterpretation may be suspected for the spelling "Piscadero" for Pescadero of the 1850 's; the pronunciation was heard clearly from an informant 89 years of age.

${ }^{43}$ Cf. the Slavic-German cases discussed by E. Kranzmeyer, "Zur Ortsnamenforschung im Grenzland," Zeitschrift für Ortsnamenforschung 10 (1934), 132. The alternative would be to show that the English phoneme inventory is drastically limited in borrowings. Cf. Pacific Northwest place-names with "ch" [J]. 
term with its English equivalent: Alambique [1æləm'bik] creek < arroyo del Alambique (after a stillhouse built by Tom Bowen in 1842). There is also one attested example of the well-known process of popular etymology: Alpine <el Pino, as well as one doubtful one (Ox hill may be from los Ajos). The Spanish definite article is hardly ever retained; ${ }^{44}$ the common elements San $\sim$, Santa $\sim$, are regularly dropped in (San) Pedro (valley, etc.), occasionally in (Santa) Clara valley and (San) Vicente creek (all three are small features within five miles of each other).

Translation of all elements in a name is surprisingly common. Nearly a third of the Spanish names adopted were treated in this way, and there may have been more, for the original is often known only from a single record. Sometimes the translation may be observed proceeding in two steps, with the generic always changing first: arroyo de los Laureles > c. 1860 "Lorelles [etc.] creek" > c. 1870 Laurel creek. There is a strong tendency to totally translate names like cañada Verde $>$ Green valley, where the specific part is bound as an adjective to the generic term. The very few names in which both elements were left untranslated (another Cañada Verde, Arroyo Honda [sic]) are also adjectival.

The remaining if unlikely possibility for these terms - an untranslated generic with a translated specific - is not found in names drawn from Spanish, but may be illustrated by one most peculiar example. A pool in San Mateo creek where Chinese fishermen washed their nets was called the Nettie Wan, explained by two or three unconvincing folk-etymological tales. The name may well be a pidgin form of 'net' followed by the Cantonese word for a pond or small body of water.

Spanish translations of English place-names are, as might be expected, occasionally attested after $1850 .{ }^{45}$

44 The exception is Las Peñas, a rocky spot on the old Bennett-Fatjo ranch, where Spanish was spoken to a late date. This appellative became a name only in English context.

45 An 1878 arroyo del Francés must render Frenchman's creek, since the latter was named from a potrero de los Franceses. The usual Spanish name was arroyo del Monte; near Spanishtown at the time there were several such "free pairs" of names unrelated in the two languages.

The well-known tree now called the Palo Alto (fifty feet across the boundary in Santa Clara County) was so named in Spanish, but not before 1850. In Sept., 1853, 
Some of the idiosyncrasies of Spanish use have been preserved in the Italian recently or still spoken in the Pacifica area. Forms such as rancio di Scatena have been current since before 1870, and owe little or nothing to English. Pedro valley, from San Pedro, was still considered a simple location, not a valley, when referred to as San Pietro. Pedro mountain is called the montagna di San Pietro. Santa Clara valley, a little hollow bearing a name given by Franciscan missionaries, is attested in Spanish only as the cañada de Santa Clara; but since in Italian it is referred to simply as Santa Chiara or Santa Clara, the generic term was presumably dropped in Spanish as well. ${ }^{46}$

It is not surprising that Spanish names with forms or applications not standard in English have been less often adopted; but it is well worth notice that their proportion has been reduced to approximately that of similar English names, or of other Spanish types. ${ }^{47}$

The development of "real-estate Spanish" will not be treated here, but some early examples of the sentimental post-Spanish application of Spanish names can be mentioned. In the 1850's a Hungarian gentleman named his farm rancho del Capuchino (hence Capuchino High School). In place-names the term usually refers to a Capuchin cypress; but at the time a number of books mistakenly claimed that the California missions had been founded by Capuchin friars, and this possible source is the more likely one. About 1878 Captain John H. Sears (for whom Searsville had been named over twenty years earlier) opened his La Honda Store, manufacturing the name from that of the misspelled Arroyo Honda; the more or less meaningless new name was soon attached to two small settlements, and the area. In 1888 a subdivision called Wellesley Park was planned; the streets bore very British names, but county records already designated a stream (popularly Finger creek) as "Cordillas creek," a misspelling derived from arroyo de los Cadillos

(within months of the first attestation of the name in a Spanish deed) an American newspaper describes a ranch as "near the Tall Tree." The Spanish form, however, is in all records from 1854 on, and when Governor Stanford found it in the deed as a by-name for his ranch, as well as commonly applied to the tree, he adopted Palo Alto for the ranch, for the railroad stop, and hence ultimately for the town.

46 Most of this information was given by the late Ernesto Nevoli.

47 See the table above, lines 6 and 7, and note 21. 
('cockleburrs'). The developers consulted a Spanish dictionary and put Cordilleras creek on the Redwood City map. ${ }^{48}$

The northern two thirds of the county, the part originally subject to San Francisco, was settled by Europeans, and by Americans from New York state and thereabouts. The language of the latter is preserved in place-names here, and still spoken in the city. ${ }^{49}$ The other third of the county, centering around Pescadero, was part of Santa Cruz County until 1868, and, like other areas beyond the San Francisco enclave, was settled by Americans from areas, on the average, slightly more interior and southerly. The difference is still audible. Within the county it was increased by the fact that the Redwoods areas north of San Gregorio were entered by lumbermen and "bachelor rancheros," while the San Gregorio valley was reached via Santa Cruz by homesteaders and their families. A supervisorial-district boundary established in 1874 along the precise line between the two areas was removed in 1950, when the differences of which people were conscious had become those between the populations living on the bay and coast sides of the mountain.

Some of the regional differences resulting from the early settlement have been mentioned; others can be found below in the register of generics. Near the edge of the Pescadero district there are occasional vacillations, such as those between Bald Knob and Bald mountain, Dark hollow and Dark Hollow gulch.

A few other points of miscellaneous lexical interest may be mentioned. 'Stone, stony' were once nearly as important in local nomenclature as 'rock, rocky.' Scape ridge has an old-fashioned form of the word 'escape' (Winston Bennett, the first settler near Portola Park, is said to have been chased all the way to the top by a shegrizzly before he found a tree). Sierra Morena is said to have been an application of a Spanish phrase for the appearance of wooded

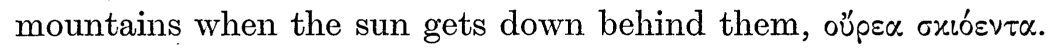

48 The Board on Geographic Names has twice had to decide in favor of the usual American spelling corruption in San Andreas lake, since there has been a minor local tendency, continued by the agencies administering the reservoir, to keep the Spanish spelling "San Andres" (though without accent). The pronunciation is not misrepresented by such early occasional spellings as "San Andrace."

${ }^{49}$ Cf. D. DeCamp, "The Pronunciation of English in San Francisco," Orbis 8 (1959), 70, 76. 
IV. Register of generic terms ${ }^{50}$

The following alphabetized register contains words used in generic positions in local English-language place-names, under the restrictions described in note 22 above. Terms omitted below for other reasons are tree, oak; street, road, avenue, boulevard (etc.); town, city; ocean, bay; peak, pass (the last two have appeared in printed sources but are not local usage - "Scarper Peak" is Scarpa hill). The capitalized terms are those that seem, from a local point of view, pseudogeneric (usually defined, for this small area, as occurring only once for any obviously distinct application). It should be stressed that this is not a vocabulary of geographical terms. The listing of any standard generic (lower-case) and the description of its use has no direct connection with past or present appellative vocabulary; cf. the obvious examples of conservatism (gulch) and innovation (chalks).

The remarks on the use of a term characterize the applications of the local names in which it occurs. Obviously less can be said about the pseudogeneric (upper-case) terms. For greater precision parenthetical references are added to point out similar appellative senses in the New English Dictionary (OED), Dictionary of American English (DAE), Webster's Third New International Dictionary (NID), and the Dictionary of Americanisms ( $D A$ ). The dictionaries are to be regarded as consulted in the above order. The abbreviation "spec.," means "specialized with respect to, and presumably from" the sense referred to; "gen.," means "generalized with respect to, etc."; "trans.," "a metaphorical application of a sense like"; "like" indicates doubt that the generic application has a direct historical connection with the particular sense. In some instances the generic applications make possible closer distinctions in the use of a term than the dictionaries seem willing to make from appellative use: see particularly hill.

The incidental remarks on the use of terms in place-names elsewhere in the state and nation are partly from personal observation, and are tentative. When a generic term seems to be a regular replace-

50 To be distinguished from broader appellative and onomastic studies: esp., G. D. McJimsey, Topographic Terms in Virginia, N.Y., 1940; E. Wallace McMullen, English Topographic Terms in Florida, 1563-1874, Gainesville, 1953; and the Linguistic Atlas collections. 
ment for a particular Spanish term in adaptations and translations of Spanish names, the formula "translates ......" is used. A number of instances are noted in which Spanish use has affected the use of English terms in particular names, if not systematically.

beach. An extent of sandy shore: the Seven Mile beach (NID 2a). The shore was mud at the San Mateo beach < playa de San Mateo (Spanish playa like OED Beach ${ }^{1}$ ).

bend. Since c. 1910 a bend in a road (spec. OED ${ }^{4} \mathrm{I} 5$ ). See below, curve and turn. Grecian Bend, c. 1870, is not the same use.

bluffs. Pescadero district only: cliffs, as in southern-interior U. S. $\left(N I D^{2} 1\right)$. Plural only.

camp. Particularly common around Pescadero and in the Santa Cruz mountains generally in names of abandoned sites (Dutch camp, Dougherty or Dirty camp for lone settlers' cabin-sites and surrounding clearings). In some instances the generic originally preceded, and the inversion to normal order seems to have been roughly contemporary with the abandonment (camp Spaulding, a resort camp, and camp Thirty Six, a family lumber camp in section 36, are now Spaulding camp and Thirty Six camp). (Spec. DAE 1d,c.)

canal. Since c. 1880 at the latest, an artificial or channelized stream bed. Not very common in appellative use; a localism? Usually represented by "creek" or "channel" in official use and on maps. (Spec. NID 4.)

canyon. The word is locally rather rare in place-names. The Spanish Californians seem to have preferred cañada 'hollow' or cajón 'box canyon.' In earlier American times canyon meant a very deep, steep chasm (OED; only in Devil's Canyon). The area around Half Moon Bay is an exception: here the Latin American immigration of the 1850's introduced cañón for all large gulches, and canyon now varies freely with gulch in many names. Elsewhere in recent decades, "canyon" has replaced "gulch" as an appellative, but not in names.

chalks. [t foks] The term seems to be a local creation. From early times the Chalks were the white sandstone ridges near the Waddell creek; in writing the name was usually normalized to "Chalk mountain." Around 1900 and 1939 two similar areas were named the Jackson chalks and Burns chalks. 
channel. Restricted in naming to dredged navigable passages through shoals (spec. OED ${ }^{14} \mathrm{~b}$ ); exception: the Belmont Channel, artificial but unnavigable, in contrast to Belmont slough.

Circle. (Like OED II 12!) Probably not a generic; see note 26 .

Corner. Used once for a three-way intersection: Adobe Corner (back-formation from corners, $D A$ 3). See junction.

cove. Only a small bay $\left(O E D^{14}\right)$.

creek. [krijk] (1) Standard American sense (DAE 2). Translates arroyo (which has not been used in English locally: 1862 "Finger's Arroyo" and "McClellan's Arroyo" on a published railroad map are sports). (2) ( $D A E$ 1) See slough.

crossing. (1) A road crossing of a railroad at grade ( $D A E 2$ ). (2) The ford of a creek (DAE 1).

curve. Since c. 1910 a bend in a road (spec. OED B 2). Uncommon. See bend, turn.

cut. The entrenchment of a road or railway ( $D A E 1 \mathrm{c})$.

Dam. (NID 22) See note 26.

Deer Park, Deer Pasture, Doe Park. Fixed names commonly given to natural clearings; Pescadero area and south at least through Monterey County. The most recent bestowal of Deer Park, however, was upon a place that had actually been used to enclose deer.

embarcadero. (DAE) Used in the 1850's; in the few names that survived, it was later replaced by landing (OED II 5).

falls. Usual sense ( $D A E \mathrm{I} 1 \mathrm{~b})$; plural only.

field. (1) An enclosed pasture or plowland (OED I 4): the Indian field, the Mine field. (2) Commonly applied to what in other parts of the state is named a meadow ( $D A E 2$; cf. below, s.v.), glade (OED 1), cienaga, potrero $(D A)$, prairie (spec. $N I D$ lc) or park (NID 5a2): a clearing among trees or brush (i.e., trans. NID 1b 1). In the Santa Cruz mountains, sometimes replaces the old term opening in names (China opening $>$ China field). The federal mapping agencies tend to substitute their own standard generic, "flat" (another China field, "China Flat"; Worley field, "Worley Flat" U.S.G.S.). See next entry.

flat. Usually bottomland along a creek, as elsewhere in the west (NID la 4). Fern fat occurs several times for small clearings, and may be a fixed name. 
forest. Only in the Butano forest, a true forest in the sense of 'large woodland'; but the name was applied in connection with conservation movements and must be considered by analogy with national-forest names.

fork. Only for a branch of a named stream: East fork of the Tunitas. See above, in the section on grammar. (DAE 1c.)

gap. As in much of the nation, a small road-pass over or between hills; not necessarily deeply sunken (gen. $D A E 2 \mathrm{~b}$ ). Translates portezuelo.

grade. ( $D A E 4)$ Mainly in names of mountain roads built between 1890 and c. 1905.

grove. A stand of redwoods; since about 1890. Cf. redwoods.

gulch. The word has wide and obscure connections with other terms ("gulp," etc.; cf. OED Gulch $v^{1}$, Gull $v^{1}$, Gulph II 3). Two that stand in closer relationship are "gully" and "gulf" (or, as often spelled when used in names of small ravines in New York, Alabama and other eastern states, "gulph" - spec. OED II 4; cf. NID 2b). Though used earlier, gulch gained its popularity in the California gold rush; in the county $60 \%$ of the gulch-names are found in the Redwoods area settled then; but the term was used locally even earlier ("Cat head Gulch" heads a note from the Pulgas redwoods, July 20, 1847 : Santa Clara County Probate Division, Est. of Thomas Bowen, no. 21).

(1) In most of the county, gulch applies to a ravine smaller than the very largest and deepest features (which are sometimes named canyon, see above s.v.) and larger than what would be called a gully. Translates zanjón (which had one other meaning, 'freshwater slough,' and could be applied to gullies). (2) In the Pescadero district the term is also applied to some features which are not very conspicuous as ravines. Here it is conceived to belong to intermittent watercourses as opposed to perennial creeks (even those in steep ravines). The distinction, though expressed in western terms, seems to be the midland and southern one between creeks and what are called branches, runs or prongs (cf., as cited in note 17 above, Zelinsky, p. 322; Raup, p. 163; DAE Run 1 quot. 1908).

hill. (1) An elevation of any size; translates loma and cerro. (2) A hillside slope (Schoolhouse hill, Pescadero). (3) A grade on a road; translates cuesta. (Most of these names have been little used since 
c. 1910). (4) A summit on a road. (5) All combinations of the foregoing; e.g., (3) - (4) Haskins hill, (2)-(3)-(4)-(5) and often (1) Dead Man's hill alias Dead Woman's hill (<la Vieja). See mountain, knoll.

Hole. Apparently originally applied in an east-coast hydronymic sense $(D A 2, D A E \mathrm{la}-\mathrm{b})$ : the Stage Hole is a pond in Pescadero creek where a stagecoach overturned before 1859; the Sand Hole was an estuary where the coast road crossed on a sandspit in the 1850's; the Big Hole was a mountainside depression with a pond.

hollow. ( $D A E$ 1) Pescadero district; this affords an exact translation of cañada. Elsewhere in the county the equivalent is valley.

island. Usual senses: land isolated by water, or hard ground isolated by marsh (OED 1,2;NID 2a 1); peninsula difficult of access (NID 1b).

junction. Pescadero district: a road intersection (NID 2c).

Knob. (OED 2) Only in Bald Knob varying with Bald mountain (the very first settlers on it were Missourians).

knoll. A small round hill (OED ${ }^{12}$ ), as elsewhere in the west. Not used in the Pescadero district, or, evidently, further south.

laguna, lagoon. From the Spanish for 'lake': the early Americans used the word for small ponds (not quite $D A E 2$ ), evidently feeling the translation would not fit. Except in the Santa Cruz mountains, later generations have substituted lake in the names. See next entry.

lake. Anything from a small pond to a large reservoir (slightly gen. $O E D$ 1, NID 2a). In some recent cases of self-conscious naming the word can come before the specific (lake Elizabeth, lake Lucerne or Lucerne lake); lake Merced seems about equally due to such patterns and to the Spanish form, and was formerly also Merced lake.

landing. See embarcadero.

lane. As elsewhere, a farm lane (nearly NID la).

Meadow. Only in the Ox Meadow, a mountain glade named in c. 1855.

Monte. ['mantr] From the Spanish for 'woods': now only in the Willow Monte, also the Willow Patch (Pescadero). The word has been used for the tall woods on the Salinas river in Monterey County (not quite NID 2). 
Mound. (NID 3c, the well-known midwestern use). Only in one name: 1857 "a mound on Howard's land"; c. 1860-70 "Howard's mound"; ever since, the Mound. The feature would normally be named a hill or knoll.

mount. (OED I) Preserved in pre-specific position in a few names for which the circumstances of naming are remembered; otherwise it becomes hill (mount Hulda > Hulda's hill, mount Lincoln > Lincoln hill).

mountain. Normally a free-standing bulk or range (NID $1 \mathrm{~b})$. Translates cerro in some instances where hill might rather have been expected. King's mountain (see above) is another exception. opening. See field.

Park. See Deer Park.

Pasture. In the Night Pasture, a fenced field. See also under Deer Park.

Pit. Only in the Macco Pit, named c. 1945 (like NID la 1, but shortened from western "borrow pit").

point. (1) Usual shoreline sense (NID 7a); translates both punta and rincón (in the latter's sense of 'headland'). In names that have been on the nautical charts since before American times, official use tends to place the generic first: "point Ano Nuevo, point San Bruno, $\sim$ San Mateo, San Pedro" (even, occasionally, "point New Year's" for the first and "point Pedro," i.e., Pedro point for the last). Popular usage has the normal word-order in all these and in Montara point, named "point Montara" by the Coast Survey c. 1871. (2) Various more or less metaphorical applications, including a peak $(D A E 3)$. (3) An overlook or view-point on a road; recent (40 years), as in the national parks (spec. $D A E 3$ ).

redwoods. An old term with no surviving representatives; usually applied to larger areas than grove: the Pulgas redwoods, the Lower redwoods, the Big redwoods (c. 1870), the Redwoods par excellence. In the 1850's usually written as two words. Syntactically singular in names, plural as appellative.

reef. Usual sense $\left(O E D^{2} 1\right)$. The Coast Survey bestowed the name "Colorado ledge" after the wreck of the steamship Colorado in 1867 , but "ledge" is not in the local generic lexicon, and the name became the Colorado reef. 
ridge. Usual sense ( $D A E 1 \mathrm{~b}$, also descending side-ridges); translates cuchilla.

river. Not now in any local names. Once used to translate rio in names of large saltwater sloughs (like NID 1c): rio de las Pulgas. Hence, elsewhere nearby, Coyote river, Napa river, etc.

rock. Usual senses (OED I1). Clam Rock is not a rock, but a place where living clams were found in a soft stratum.

saca, saka, sacha, etc. ['sekə] From Spanish acequia. After c. 1845 applied by Americans to the main irrigating ditch of San Jose; this later became a localism for a natural ditch, an overflow or alternate stream channel, but died out after 1900. In San Mateo County, only in "the saca Aurora" 1850, with Spanish word-order. (Cf. for similar southwestern uses, $D A E$ Sequia quot. 1870; E. Bagby Atwood, The Regional Vocabulary of Texas, Austin, 1962, p. 91 note; T. M. Pearce, American Speech 33 (1958), 106.)

shoals. Usual sense $\left(O E D^{1}\right)$; plural only.

slide. Recently, as elsewhere, in names for a landslide area ( $D A E$ 1). Devil's slide, a dangerous cliff where the coast highway is frequently carried away, has its name by inadvertence from the Devil's Slide, a rock formation of the sort commonly so named.

slough. [slu] The standard word in most of California for a tidal channel (NID 1c2). In the county, as elsewhere in the San Francisco district, creek (in the original sense, $O E D \mathrm{I} 1$ ) can be freely substituted in any of the names. Either word translates estero, but the phrase los esteros lies back of the present term for the bay marsh, the sloughs. Real-estate men now consider slough an offensive word. In 1957 they held a public contest for renaming Seal or San Mateo slough. A housewife's prizewinning suggestion, the Marina-Lagoon, is now usually reinterpreted as the Marina lagoon, hence altered to the Lagoon or (by boat-owners) to Marina slough!

spring. Usual sense (OED I2); very few examples; one of plural (blend with $D A E \mathrm{lb}$ ).

Timbers. See note 23 above.

turn. The old term for a bend in the road (OED II11). See bend and curve.

valley. Outside of the Pescadero district, a hollow.

University of Arizona 